\title{
USE OF DIFFERENT APPROACHES FOR THE BEST FACTORY LAYOUT
}

\section{VujicA HerZoG, N., BuChMEISTER, B., \& OJSTERSEK, R.}

Abstract: Production design is a complex task that can be solved using a variety of approaches. The range of knowledge in this field is wide, but this paper is about understanding how it works in a general way, using the tools available nowadays, mostly referred to as Industry 4.0. Required data for the problem presented was taken from the literature and supplemented with the real life data. The problem was solved using different computer programs from Autodesk family with different computer simulations. For the final layout design, simulations were performed using the program Autodesk Process Analysis. All product flows were described and analysed to find the best solution. The global idea made with this work can help us to better understand how a factory layout can be designed and elaborated using different computer tools.

Key words: factory layout, optimization, simulations, industry 4.0
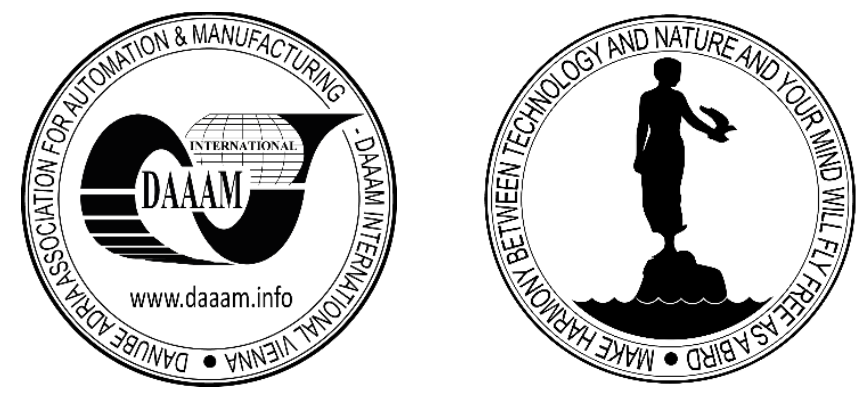

Authors' data: Assoc. Prof. Dr. Sc. Vujica Herzog, N[atasa], Full. Prof. Dr. Sc. Buchmeister, B[orut]; Asist. Prof. Dr. Sc. Ojstersek, R[obert];University of Maribor, Faculty of Mechanical Engineering, Smetanova 17, 2000 Maribor, Slovenia, natasa.vujica@um.si, borut.buchmeister@um.si, robert.ojstersek@um.si

This Publication has to be referred as: Vujica Herzog, N[atasa]; Buchmeister, B [orut] \& Ojstersek, R[obert] (2021). Use of Different Approaches for the Best Factory Layout, Chapter 05 in DAAAM International Scientific Book 2021, pp.051-068, B. Katalinic (Ed.), Published by DAAAM International, ISBN 978-3-902734-31-0, ISSN 1726-9687, Vienna, Austria

DOI: $10.2507 /$ daaam.scibook.2021.05 
Vujica Herzog, N.; Buchmeister, B. \& Ojstersek, R.: Use of Different Approaches f...

\section{Introduction}

Production design is a very complex task that can be approached from several areas, each of which offers its own solution to a particular problem (Buchmeister et al, 2019; Francis et al., 1991; Gajšek \& Vujica Herzog, 2020; Harari et al., 20217; Marjanović at al., 2020; Prester et al., 2018; Taha, 2006; Vujica Herzog et al., 2019). The range of knowledge in this field is wide (Pinedo, 2009; Slack, 2019; Tompkins et al., 2002; Ojstersek et al., 2020; Yang et al., 2019), but the scope of this article is to show the case of the problem solving approach that is mostly mentioned nowadays and is known as Industry 4.0. The aim of the presented research is to solve a complex problem from the book Manufacturing Facilities, written by Dileep R. Sule (Sule, 2005), with different computer programs and using different computer simulations. Six products were designed with their own workflow. The programs used are from the Autodesk family. For the 2D development of the layout, AutoCAD, AutoCAD Mechanical and AutoCAD Architecture were used. For 3d modelling, Autodesk Inventor Professional and for simulations Autodesk Process Analysis. All of them had integrated the package Autodesk Factory Design Utilities (Autodesk, 2020) for better understanding and development.

\section{Problem description}

For the production system study to be solved, we have taken all possible data from the book Manufacturing Facilities, written by Dileep R Sule, especially Appendix F: Case Studies, Case Study 1: Plant Design Project. The case is very accurate in terms of reality and so is the data. Missing data for simulations or planning design were obtained from real life. If the data varies from the exercise, it is because we want to improve the project and the way is explained.

The main components of the project can be summarised as follows:

- Three facilities will need to be established at 7 possible locations.

- Six products will be produced with six different workflows and production volumes

- Eight functional units make up the production area: tool room, injection moulding, assembly, machining, finishing, heat treatment, forming and testing plus the additional step of storage.

- The general layout must be calculated with some criteria.

- The number of forklifts is required.

- Process simulations are required.

\subsection{Facility place selection}

The company wants to place three new facilities. Among all possible seven options, only 3 of them are selected. The only two criteria for selecting the better option are the transportation cost and the fixed cost per year. Table 1 shows how they are related. According to the presented problem, three locations were assigned to the 5 distribution centres. 
Some constraints were considered: Distribution centre 3 cannot be served if the facility is located in 5 or 6 and that distribution centre 2 cannot be served if the facility is located in 7 . These requirements automatically block several possible combinations.

\begin{tabular}{|c|c|c|c|c|c|c|c|c|c|}
\hline $\begin{array}{c}\text { Distribution } \\
\text { center }\end{array}$ & Site 1 & Site 2 & Site 3 & Site 4 & Site 5 & Site 6 & Site 7 & $\begin{array}{c}\text { Trips per } \\
\text { month }\end{array}$ & $\begin{array}{c}\text { frips per } \\
\text { year }\end{array}$ \\
\hline 1 & 64 & 102 & 58 & 198 & 224 & 105 & 90 & 44 & 528 \\
\hline 2 & 12 & 76 & 94 & 154 & 166 & 94 & 74 & 38 & 456 \\
\hline 3 & 168 & 212 & 88 & 38 & 66 & 121 & 68 & 52 & 624 \\
\hline 4 & 112 & 148 & 124 & 82 & 20 & 77 & 55 & 32 & 384 \\
\hline 5 & 94 & 119 & 111 & 88 & 49 & 40 & 210 & 49 & 588 \\
\hline $\begin{array}{l}\text { Fixed cost per } \\
\text { year }(€)\end{array}$ & 38340 & 34210 & 39450 & 33940 & 29220 & 36654 & 32119 & & \\
\hline * Cost is calculated in euros e.g., for distribution center 1 Site 1 costs are 64€. \\
\hline
\end{tabular}

Tab. 1. Transportation Cost Matrix

For location selection, procedure matrices were created with key information extracted from them. First, Table 2, which shows the cost of each operator train multiplied by the number of trains, giving the demand cost of each combination, e.g. Site1 - Centre 1 is $€ 33792$ after multiplying $€ 64$ times 528 trains per year. Prohibited options are marked with NO.

\begin{tabular}{|c|c|c|c|c|c|c|c|}
\hline Distribution center & Site 1 & Site 2 & Site 3 & Site 4 & Site 5 & Site 6 & Site 7 \\
\hline 1 & 33792 & 53856 & 30624 & 104544 & 118272 & 55440 & 47520 \\
\hline 2 & 5472 & 34656 & 42864 & 70224 & 75696 & 42864 & NO \\
\hline 3 & 104832 & 132288 & 54912 & 23712 & NO & NO & 42432 \\
\hline 4 & 43008 & 56832 & 47616 & 31488 & 7680 & 29568 & 21120 \\
\hline 5 & 55272 & 69972 & 65268 & 51744 & 28812 & 23520 & 123480 \\
\hline
\end{tabular}

*Demand cost unit is $€$ because trips have no units.

Tab. 2. Demand Cost

In the next step, we tried to find the smallest demand cost for the distribution centres. We calculate the savings of placing the facility in one location rather than placing it in the location with the smallest demand cost. With the fixed costs in the negative (because it is something that needs to be invested regardless of the distribution centre, it is location dependent), adding the savings plus the fixed costs gives the net savings and the lowest value is the best option. For example, for centre 1, the smallest values are at location 3, €30624, and the second smallest is location 1 with $€ 33792$. The savings from switching from site 1 to site 3 is 33792 - 30624 equals $€ 3168$. The net saving would then be $-39450+3168$ equal to $-36282 €$.

As can be seen in Table 3, Site 1 has the smallest net savings, so Site 1 is selected and marked with an $\mathrm{X}$ in Table 4. When the first option is selected, the procedure changes a little. New questions emerge that need to be answered in order to follow the site selection: Would it be worth changing the location from Site 1 to a different location for each of the distribution centres? 
Vujica Herzog, N.; Buchmeister, B. \& Ojstersek, R.: Use of Different Approaches f...

To answer them, the demand cost of site 1 (Table 2) must be taken and then the demand cost of the corresponding site and distribution centre (the one that might be a better option) must be subtracted. If the result is positive, which means that it is worth swapping the items, the value of the saving is used and in any other case a letter (-) is assigned. For example, the demand cost 3 for location 1 is $104832 €$, if we subtract the demand cost for location 2, we get a negative value, so it is not worth it. But for site 3 it seems to be $49920 €$, then it is a good option to change the selection made before.

\begin{tabular}{|c|c|c|c|c|c|c|c|}
\hline Distribution center & Site 1 & Site 2 & Site 3 & Site 4 & Site 5 & Site 6 & Site 7 \\
\hline 1 & & & 3168 & & & & \\
\hline 2 & 29184 & & & & & & NO \\
\hline 3 & & & & 18720 & NO & NO & \\
\hline 4 & & & & & 13440 & & \\
\hline 5 & & & & & & 5292 & \\
\hline Fixed cost per year $(€)$ & -38340 & -34210 & -39450 & -33940 & -29220 & -36654 & -32119 \\
\hline Net savings (€) & -9156 & -34210 & -36282 & -15220 & -15780 & -31362 & -32119 \\
\hline * Saving units are $€$, e.g., distribution center 2 Site 1 savings are 29184€. \\
\hline
\end{tabular}

Tab. 3. Initial Assignment Minimum Saving Table

\begin{tabular}{|c|c|c|c|c|c|c|c|}
\hline Distribution center & Site 1 & Site 2 & Site 3 & Site 4 & Site 5 & Site 6 & Site 7 \\
\hline 1 & $\mathrm{X}$ & & & & & & \\
\hline 2 & $\mathrm{X}$ & & & & & & NO \\
\hline 3 & $\mathrm{X}$ & & & & NO & NO & \\
\hline 4 & $\mathrm{X}$ & & & & & & \\
\hline 5 & $\mathrm{X}$ & & & & & & \\
\hline
\end{tabular}

Tab. 4. Demand Assignments I

When the first option is selected, the procedure varies a little. New questions emerge that need to be answered in order to proceed with site selection; would it be worth changing the location from site 1 to another for each of the distribution centres? To answer them, the demand cost of location 1 (Table 2) must be taken and then the demand cost of the corresponding location and distribution centre (the one that might be a better option) must be subtracted. If the result is positive, which means that it is worth swapping the items, the value of the saving is used and in any other case a letter (-) is assigned. For example, the demand cost 3 for location 1 is $104832 €$, if we subtract the demand cost for location 2, we get a negative value, so it is not worth it. But for site 3 it seems to be $49920 €$, then it is a good option to change the selection made before.

The next step is to add the result to the fixed cost (that is negative), and again, if the result is positive, it is a good idea to change the location. Finally, among all positive values, the biggest one should be taken as the best option (biggest saving) and all chosen distribution centres should be "moved". For location 3, 49920€ $-39450 €$ is positive and $13638 €$. Tables 5, 6 and 7 illustrate the method. Note that some of the options are forbidden, even if the figures say that they bring greater savings, they cannot be placed there. 


\begin{tabular}{|c|c|c|c|c|c|c|c|}
\hline Distribution center & Site 1 & Site 2 & Site 3 & Site 4 & Site 5 & Site 6 & Site 7 \\
\hline 1 & $\mathrm{X}$ & - & 3168 & - & - & - & - \\
\hline 2 & $\mathrm{X}$ & - & - & - & - & - & NO \\
\hline 3 & $\mathrm{X}$ & - & 49920 & 81120 & NO & NO & 62400 \\
\hline 4 & $\mathrm{X}$ & - & - & 11520 & 35328 & 13440 & 21888 \\
\hline 5 & $\mathrm{X}$ & - & - & 3528 & 26460 & 31752 & - \\
\hline Fixed cost/ year $(€)$ & -38340 & -34210 & -39450 & -33940 & -29220 & -36654 & -32119 \\
\hline Net savings $(€)$ & -38340 & -34210 & 13638 & 62228 & 32568 & 8538 & 52169 \\
\hline
\end{tabular}

Tab. 5. Savings Table for Moving from Location

\begin{tabular}{|c|c|c|c|c|c|c|c|}
\hline Distribution center & Site 1 & Site 2 & Site 3 & Site 4 & Site 5 & Site 6 & Site 7 \\
\hline 1 & $\mathrm{X}$ & & & & & & \\
\hline 2 & $\mathrm{X}$ & & & & & & NO \\
\hline 3 & & & & $\mathrm{X}$ & $\mathrm{NO}$ & $\mathrm{NO}$ & \\
\hline 4 & & & & $\mathrm{X}$ & & & \\
\hline 5 & & & & $\mathrm{X}$ & & & \\
\hline
\end{tabular}

Tab. 6. Demand Assignments II

In conclusion, the same procedure and reasoning as in the previous cases must be followed, leading to the final site selection for all facilities.

\begin{tabular}{|c|c|c|c|c|c|c|c|}
\hline $\begin{array}{c}\text { Distribution } \\
\text { center }\end{array}$ & Site 1 & Site 2 & Site 3 & Site 4 & Site 5 & Site 6 & Site 7 \\
\hline 1 & $\mathrm{X}$ & - & 3168 & - & - & - & - \\
\hline 2 & $\mathrm{X}$ & - & - & - & - & - & $\mathrm{NO}$ \\
\hline 3 & - & - & - & $\mathrm{X}$ & $\mathrm{NO}$ & $\mathrm{NO}$ & - \\
\hline 4 & - & - & - & $\mathrm{X}$ & 23808 & 1920 & 10368 \\
\hline 5 & - & - & - & $\mathrm{X}$ & 22932 & 28224 & - \\
\hline $\begin{array}{c}\text { Fixed cost per } \\
\text { year }(€)\end{array}$ & -38340 & -34210 & -39450 & -33940 & -29220 & -36654 & -32119 \\
\hline Net savings $(€)$ & -38340 & -34210 & -36282 & -33940 & 17520 & -6510 & -21751 \\
\hline
\end{tabular}

Tab. 7. Savings Table for Moving from Site 1 to Site 4

\begin{tabular}{|c|c|c|c|c|c|c|c|}
\hline Distribution center & Site 1 & Site 2 & Site 3 & Site 4 & Site 5 & Site 6 & Site 7 \\
\hline 1 & $\mathrm{X}$ & & & & & & \\
\hline 2 & $\mathrm{X}$ & & & & & & NO \\
\hline 3 & & & & $\mathrm{X}$ & $\mathrm{NO}$ & $\mathrm{NO}$ & \\
\hline 4 & & & & & $\mathrm{X}$ & & \\
\hline 5 & & & & & $\mathrm{X}$ & & \\
\hline
\end{tabular}

Tab. 8. Demand Assignments III

As shown in Table 8, the final location of the facility will be: Distribution Centre 1 and 2 at Site 1, Distribution Centre 4 and 5 at Site 5, and Distribution Centre 3 at Site 4. A reasonable criterion was followed, which amounts to this distribution being the best option from a transportation cost perspective, while respecting the prohibited combinations. There could be other constraints, such as safety issues or legal prohibitions, but that would be another viewpoint of the calculation. 
Vujica Herzog, N.; Buchmeister, B. \& Ojstersek, R.: Use of Different Approaches f...

\subsection{Layout}

The space calculations were made taking into account all available information (Fig. 1). Some variations were made to fit the data. The workflow of product number 1 was varied to avoid three steps (treat, store and process). The decision was made because the step "treat" was not specified and the resulting sequence "machine - store machine" is meaningless.

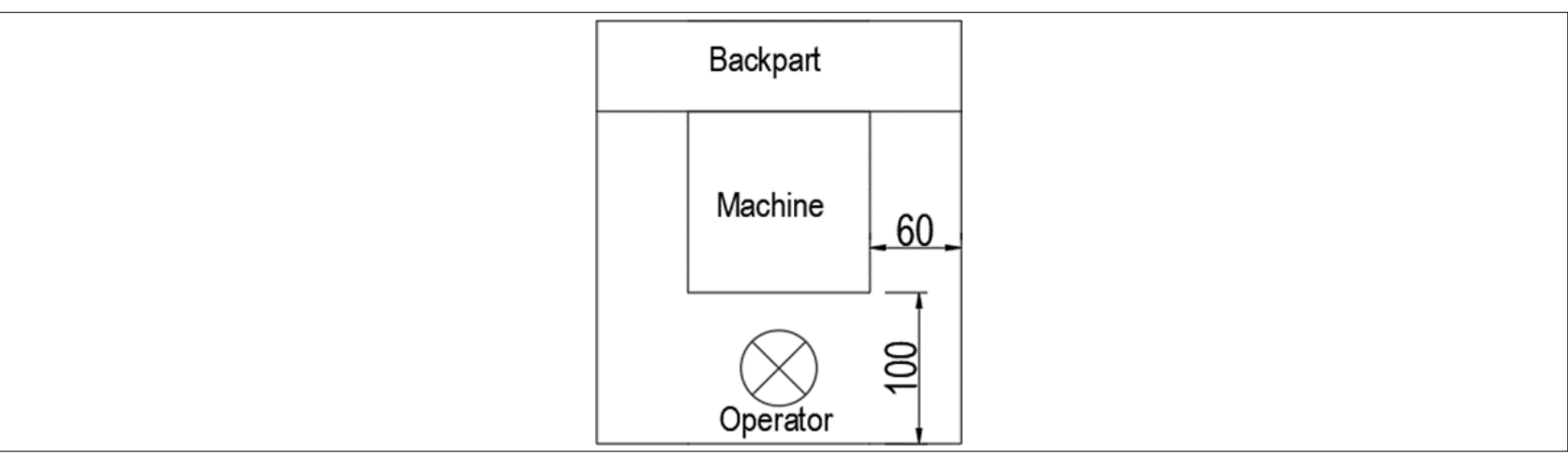

Fig. 1. Machine area with supplemented space

In the presented study, we focused on the production area of the plant, where only the warehouse, heat treatment, machining or test department is needed. The calculation of the above sections was calculated based on the machining area. In Table 9, the machining area has already been expanded by $50 \%$ compared to the data in the case. Once the machining area is fully described, the unknown areas can be derived with simple relationships in terms of percentages, an additional $50 \%$ for the assembly area and $20 \%$ less for the rest.

\begin{tabular}{|c|c|c|c|c|}
\hline \multirow{2}{*}{ Machine } & \multicolumn{2}{|c|}{ Area (feet) } & \multirow{2}{*}{ Number of machines } & \multirow{2}{*}{ Space $\left(\right.$ feet $^{2}$ ) } \\
\cline { 2 - 5 } & Length & Width & 2 & 247,5 \\
\hline 1 & 7,5 & 16,5 & 4 & 144,0 \\
\hline 2 & 6,0 & 6,0 & 1 & 63,0 \\
\hline 3 & 10,5 & 6,0 & 1 & 263,2 \\
\hline 4 & 19,5 & 13,5 & 3 & 81,0 \\
\hline 5 & 6,0 & 4,5 & 1 & 94,5 \\
\hline 6 & 10,5 & 9,0 & & 893,2 \\
\hline Subtotal & & & & 178,6 \\
\hline Extra-20\% & & & & \\
\hline Total & & & & \\
\hline *Area calculated as length x width; each dimension already augmented ina 50\%. & \\
\hline
\end{tabular}

Tab. 9. Machining area

Table 10 gives the number and size of machines for the processing area (production area + warehouse + shipping + maintenance), 12 machines in total. The size of each machine was increased by $50 \%$ to approximate reality, and an additional $20 \%$ was added for walkways (within each production area, not the entire production facility) and walls. Space calculations were performed based on these 12 machines. 
Next, each operation was assigned 1 operator per machine, resulting in the need for 4 machines for machining, 3 for forming, 1 for heat treating, or 1 for injection moulding. The machines were then selected from the Factory Design Inventor library, although the real dimensions could vary a little. The machine environment was oversized as follows: an additional $60 \mathrm{~cm}$ on 3 of 4 sides for maintenance operations and $1 \mathrm{~m}$ on the side where the operator works.

\begin{tabular}{|l|c|c|c|}
\hline $\begin{array}{l}\text { Production floor + Storage } \\
\text { + Shipping + Maintenance }\end{array}$ & $\begin{array}{c}\text { Relation with } \\
\text { machining }\end{array}$ & Space $\left(\right.$ feet $\left.^{2}\right)$ & Space $\left(\mathrm{m}^{2}\right)^{*}$ \\
\hline Injection molding & $-20 \%$ & 858 & 80 \\
\hline Assembly & $50 \%$ & 1608 & 149 \\
\hline Machining & 0 & 1072 & 100 \\
\hline Finishing & $-20 \%$ & 858 & 80 \\
\hline Heat treating & $-20 \%$ & 858 & 80 \\
\hline Forming & $-20 \%$ & 858 & 80 \\
\hline Testing & $-20 \%$ & 858 & 80 \\
\hline Subtotal production & $-20 \%$ & 6967 & 647 \\
\hline Warehousing/Storage & $-20 \%$ & 858 & 80 \\
\hline Shipping and Receiving & $1 / 8$ total production & 858 & 80 \\
\hline Maintenance & $8 \%$ total production & 557 & 52 \\
\hline Tool-room & \multicolumn{2}{|l|}{} \\
\hline Total & \multicolumn{2}{|l|}{} \\
\hline$* 1$ feet ${ }^{2}=0,0929 \mathrm{~m}^{2}$ & \multicolumn{2}{|l|}{} \\
\hline
\end{tabular}

Tab. 10. Extended space

The most important part of the factory is the production area zone (Table 11). Optimization of the layout and method to obtain the best distribution is required. The following tables show the different areas and relations (in number of operator movements per day).

\begin{tabular}{|c|c|c|c|}
\hline Department & Area $\left(\mathrm{m}^{2}\right)$ & Department & Area $\left(\mathrm{m}^{2}\right)$ \\
\hline Tool-room (A) & 52 & Heat treating (F) & 80 \\
\hline Injection molding (B) & 80 & Forming (G) & 80 \\
\hline Assembly (C) & 149 & Testing (H) & 80 \\
\hline Machining (D) & 100 & Storage (I) & 80 \\
\hline Finishing (E) & 80 & & \\
\hline
\end{tabular}

Tab. 11. Production Area Considerations

\begin{tabular}{|c|c|c|c|c|}
\hline Product & Units/Day & Units/Load & Trips/Day & Sequence of operation \\
\hline 1 & 358 & 4 & 90 & I, G, D, E, H, I \\
\hline 2 & 310 & 50 & 7 & I, C, I \\
\hline 3 & 1120 & 15 & 75 & I, D, C, D, E, I \\
\hline 4 & 18 & 1 & 18 & I, G, D, C, I \\
\hline 5 & 150 & 12 & 13 & I, F, G, E, I \\
\hline 6 & 3100 & 50 & 62 & I, B, E, I \\
\hline
\end{tabular}

Tab. 12. Sequence of Operations 
Vujica Herzog, N.; Buchmeister, B. \& Ojstersek, R.: Use of Different Approaches f...

Each of the six different products produced in the factory has a different sequence of operations. Table 12 shows the sequence of operations, as well as showing the movements to the tool room (Table 13) or the additional movements to the warehouse when assembly is required (Table 14).

\begin{tabular}{|l|c|}
\hline Production Area & Moves/Day \\
\hline Forming & 11 \\
\hline Machining & 41 \\
\hline Heat treating & 15 \\
\hline Finishing & 19 \\
\hline Assembly & 27 \\
\hline Injection molding & 14 \\
\hline Testing & 6 \\
\hline
\end{tabular}

Tab. 13. Moves from different locations to the tool-room

\begin{tabular}{|c|c|c|c|c|}
\hline Product & Units/Assembly & Units/Load & Extra units/Day & Trips/Day* \\
\hline 2 & 2 & 200 & 620 & 8 \\
\hline 3 & 5 & 100 & 5600 & 112 \\
\hline 4 & 1 & 20 & 18 & 2 \\
\hline *Go and return are counted two times, e.g. 8 trips means 4 travels from storage to assembly \\
\hline
\end{tabular}

Tab. 14. Extra products needed for assembly from the storage

The information gathered is important to know the importance of two functional units being together or as close as possible. All moves are done with forklifts; therefore, it is important to know the distance. The longer the distance, the higher the cost.

\section{Methods}

Simulations were performed using the program Autodesk Process Analysis. The missing information was taken from the literature and some was added from real life. The common features to all the simulations can be highlighted as follows:

- The simulation time was limited to 780 min (two 8-hour production shifts minus one and a half hours of time lost for various breaks).

- The transport time from one department to another was taken from Table 15.

- Transport time adds 20 additional seconds in each shift, 10 seconds for loading and unloading lots.

- Material sources require an output rate for the material coming out of the warehouse.

This output cannot be the number of products to be produced divided by the number of production hours, but should also take into account the time lost due to production and transportation problems.

\begin{tabular}{|l|c|l|c|}
\hline Forklift 1 & & Forklift 4 & \\
\hline Trips / day & 90 & Trips / day & 18 \\
\hline Total distance (m) / day & 7959,6 & Total distance $(\mathrm{m}) /$ day & 1170,0 \\
\hline Total time (min)/ day & 174,1 & Total time $(\mathrm{min}) /$ day & 25,6 \\
\hline
\end{tabular}




\begin{tabular}{|l|c|l|c|}
\hline \multicolumn{2}{|l|}{} & \multicolumn{2}{l|}{} \\
\hline Forklift 2 & & Forklift 5 & 13 \\
\hline Trips / day & 7 & Trips / day & 847,6 \\
\hline Total distance (m) / day & 179,2 & Total distance (m) / day & 18,5 \\
\hline Total time / day & 3,9 & Total time (min)/ day & \\
\hline \multicolumn{2}{|l|}{} & & 62 \\
\hline Forklift 3 & & Forklift 6 & 58,0 \\
\hline Trips / day & 75 & Trips / day & 78,7 \\
\hline Total distance (m) / day & 6795,0 & Total distance (m) / day & \\
\hline Total time (min)/ day & 148,6 & Total time (min)/ day & 122 \\
\hline \multicolumn{2}{|l|}{} & Forklift ASS & 1561,6 \\
\hline Forklift TR & & Trips / day & 34,2 \\
\hline Trips / day & 133 & Total distance (m) / day & \\
\hline Total distance (m) / day & 19165,8 & Total time (min)/ day & \\
\hline Total time (min)/ day & 419,2 & & \\
\hline
\end{tabular}

Tab. 15. Forklift information

\section{Results and discussion}

To determine the block distribution, graphs are used with a colour code representing the importance of the relationship (Fig. 2). The idea is very simple, each circumference represents one of the different divisions and they are connected by the coloured lines.

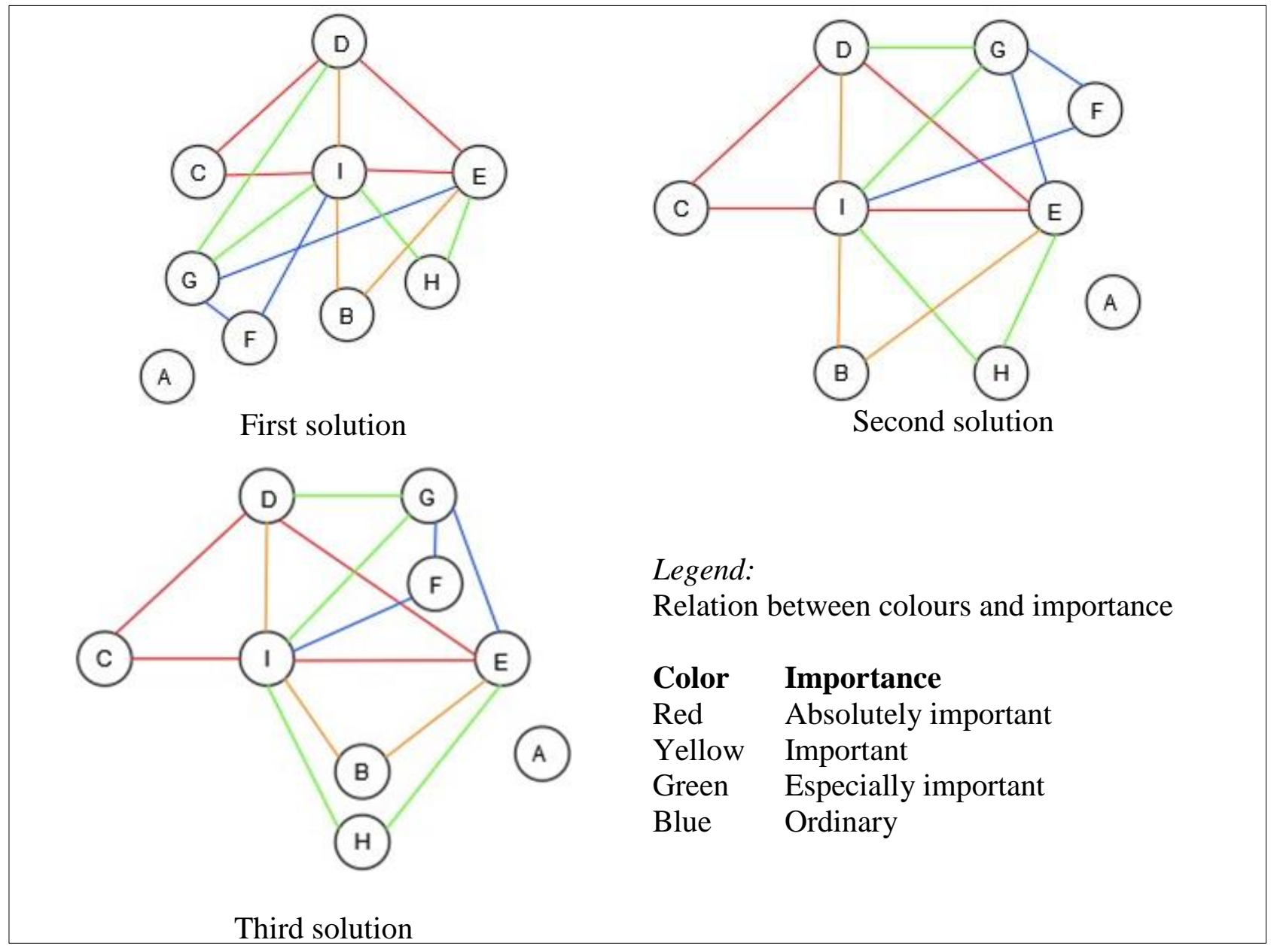

Fig. 2. Three different solutions 
Vujica Herzog, N.; Buchmeister, B. \& Ojstersek, R.: Use of Different Approaches f...

The key is that the less lines that cross, the better for the workflow, and it would be easier to have a smoother layout. The lines that originate from A (tool room) are not shown because they belong to the less important category and affect almost all departments that convert the drawing into a mesh. Several options were thought through before coming to a final decision.

As can be observed from the first to the third sketch, the drawing has developed in a much more efficient distribution, with fewer crossing lines. Most importantly, the red and green lines do not cross, while the blue are meaningless. A further step is to distribute these ideas in a physical layout. Figure 2 shows how many blocks each of the divisions should have. They are initially distributed in an 8x11 rectangle. The option achieved may not be as exact as the planned idea, but it will resemble it. The following figure shows an initial plan, showing both the block distribution individually and an overall view (Fig. 3).

\begin{tabular}{|c|c|c|c|c|c|c|c|c|c|c|c|}
\hline \multirow{2}{*}{\multicolumn{3}{|c|}{ Machining }} & \multirow{4}{*}{ Heat-treating } & () & () & () & () & () & () & () & () \\
\hline & & & & (ㄹ) & () & () & () & (ㄹ) & () & () & () \\
\hline \multirow{9}{*}{ Assembly } & \multirow{2}{*}{\multicolumn{2}{|c|}{ Finishing }} & & () & () & (ㄹ) & () & () & () & ¡ & 다 \\
\hline & & & & (C) & () & () & () & () & () & () & 두 \\
\hline & \multirow{3}{*}{\multicolumn{2}{|c|}{ Storage }} & \multirow{4}{*}{ Forming } & (c) & (C) & (1) & (1) & (1) & () & () & () \\
\hline & & & & (C) & (C) & (1) & (1) & (1) & (ㄷ) & () & () \\
\hline & & & & () & () & (1) & (1) & (1) & $(\oplus$ & () & () \\
\hline & \multirow{4}{*}{$\begin{array}{l}\text { Injection } \\
\text { molding }\end{array}$} & \multirow{4}{*}{ Testing } & & () & () & (B) & () & $\oplus$ & $\oplus$ & (ㄷ) & () \\
\hline & & & \multirow{3}{*}{ Tool-room } & () & (c) & () & () & $\Theta$ & $\oplus$ & (A) & (A) \\
\hline & & & & () & (c) & () & () & $\Theta$ & $\Theta$ & (A) & (A) \\
\hline & & & & (C) & () & () & () & $\Theta$ & $(\oplus$ & (A) & (A) \\
\hline
\end{tabular}

Fig. 3. Block diagram and first layout

The introduction of aisles, walls and doors change the layout and later machines are added. The final distribution with all dimensions (in $\mathrm{mm}$ ) and the indicated area of each department are shown in Fig. 4. 


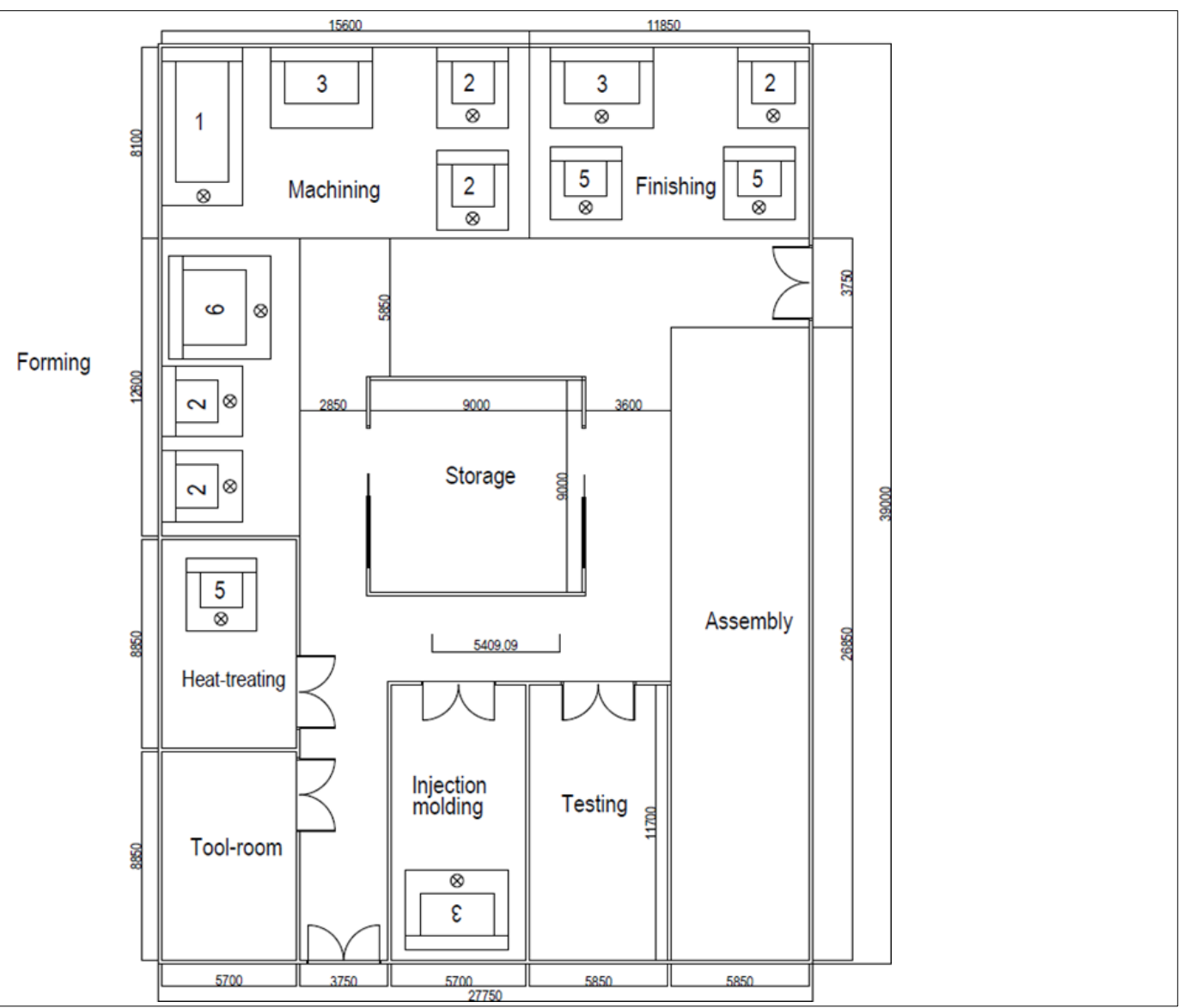

Fig. 4. Final layout

If we transfer the AutoCAD designs to the Inventor program, we obtain the following 3D model (Fig. 5).

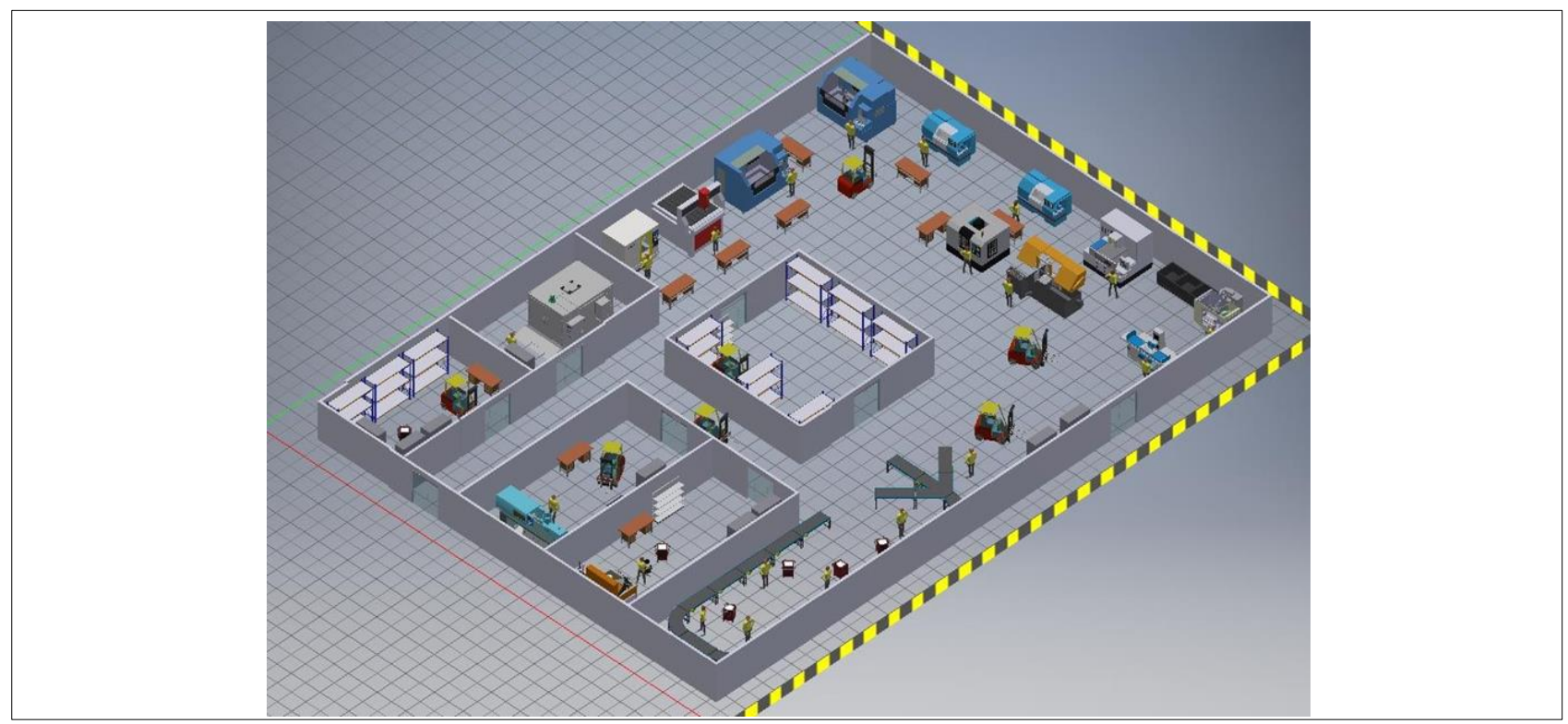

Fig. 5. Layout - 3D model

AutoCAD mechanical has the necessary tools to determine the individual workflow for each product. All paths start and end at the same place - the bearing, while following their corresponding operations. The illustrations for each path are shown below (Fig. 6 and 7). 
Vujica Herzog, N.; Buchmeister, B. \& Ojstersek, R.: Use of Different Approaches f...

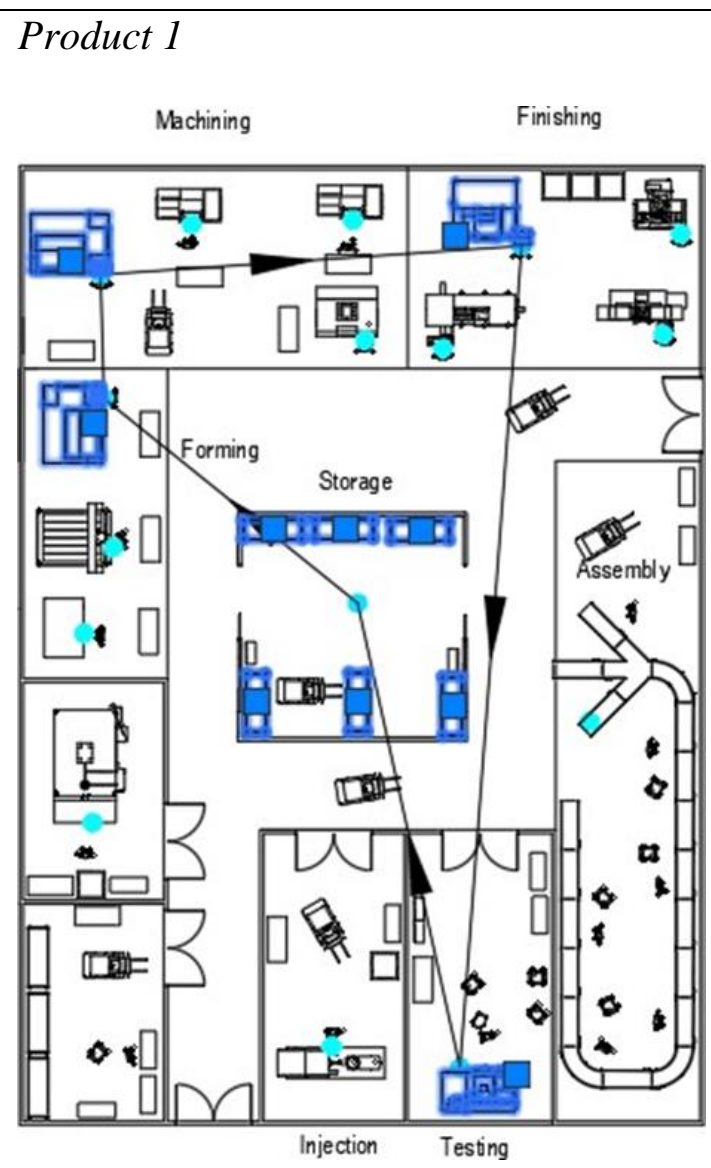

Product 2

Product 3

Machining

Finishing

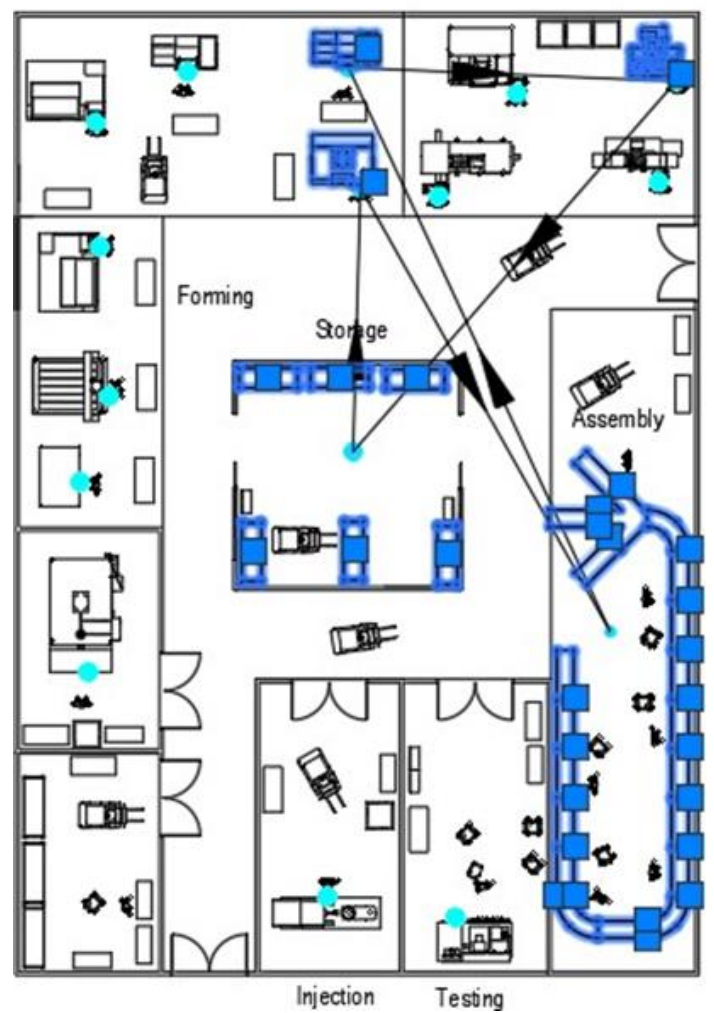

Machining

Finishing

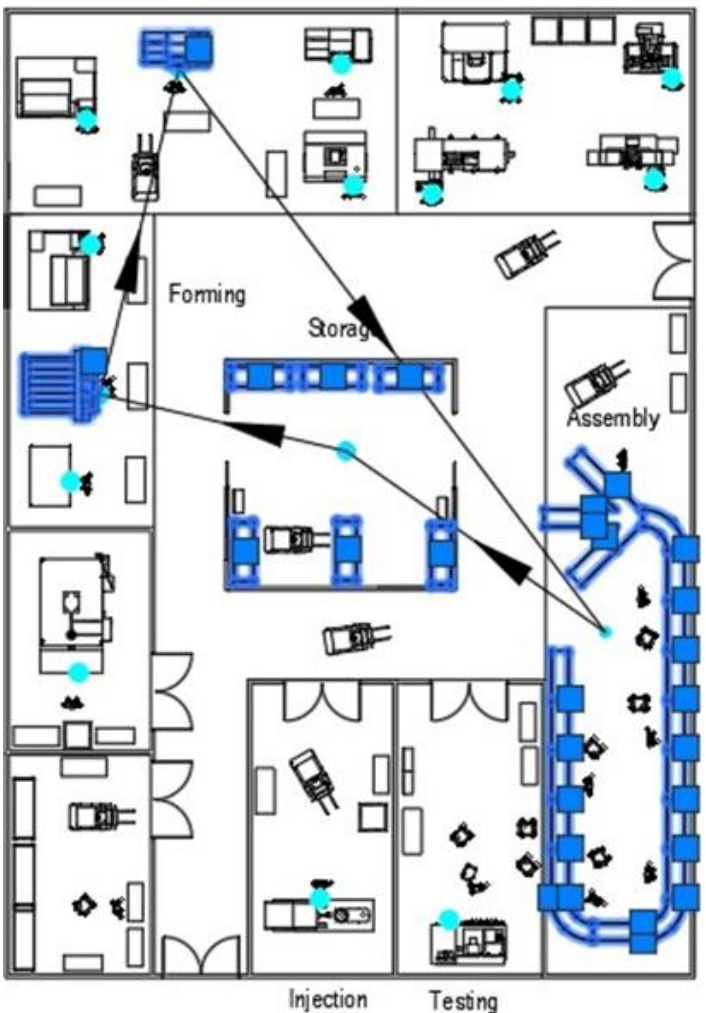

Fig. 6. Workflow for products 1-4 


\begin{tabular}{lll}
\hline DAAAM INTERNATIONAL SCIENTIFIC BOOK $2021 \quad$ pp. 051-068 & Chapter 05 \\
\hline
\end{tabular}

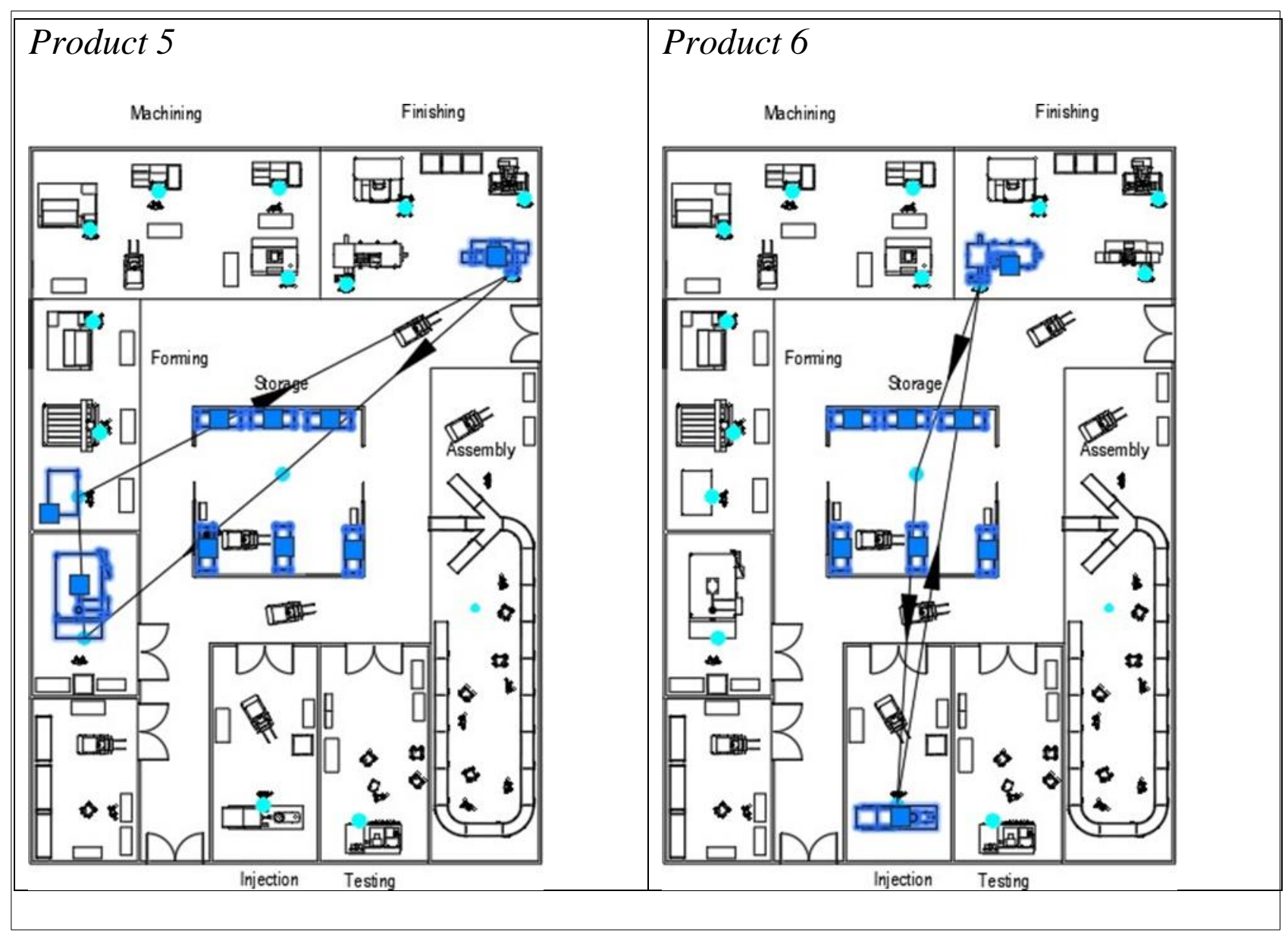

Fig. 7. Workflow for products 5-6

Forklift calculations were also performed for accurate simulation results. We planned eight forklifts, six of them for different products and two others for movements to the tool room and movements between the warehouse and assembly. A forklift speed of $0.76 \mathrm{~m} / \mathrm{s}$ was considered for the calculations. The results of the process analysis were recorded with the tool Autodesk Process Analysis.

The workflow for product 1 can be seen schematically in Figure 8, while it is clearly defined with spatial dimensions in Figure 6. It starts with storage, followed by the sequence of forming, machining, finishing, testing and finally storage again. Each load carries 4 units and the machining time was defined for all machines as follows:

- 1-1 Forming, 1-3 Finishing, 1-4 Testing: 1 pc / $70 \mathrm{~s}$.

- 1-2: Machining: 1 piece / $80 \mathrm{~s}$

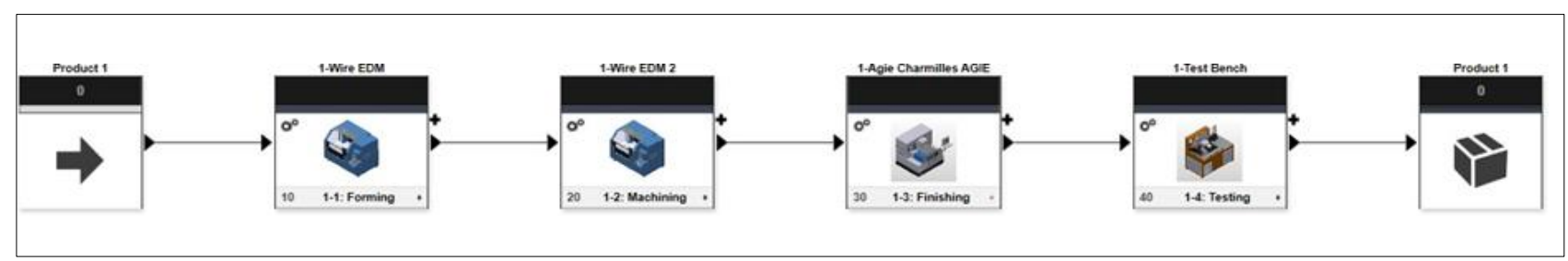

Fig. 8. Workflow for product 1

Machine efficiency for product 1 is shown on Fig. 9 
Vujica Herzog, N.; Buchmeister, B. \& Ojstersek, R.: Use of Different Approaches f...

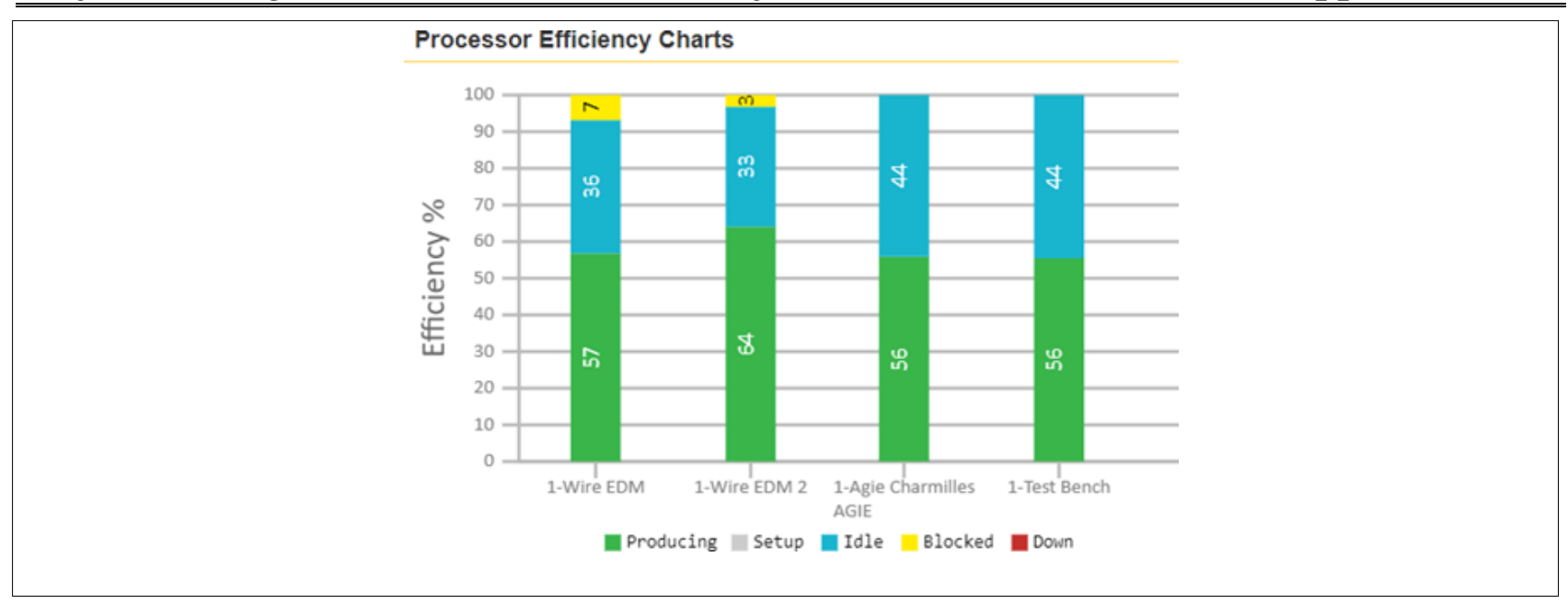

Fig. 9. Machine efficiency for product 1

After simulation, 368 pieces were produced, 10 more than required by the literature. The machine with the highest productivity is Wire EDM 2 with a $64 \%$. The workflow is really smooth and fluid in the simulation, there is no machine that has to wait for a long time for a previous department, they are very well placed and the waiting time is mainly due to the only fact of the distance between zones, having similar machining times helps to simplify the simulation.

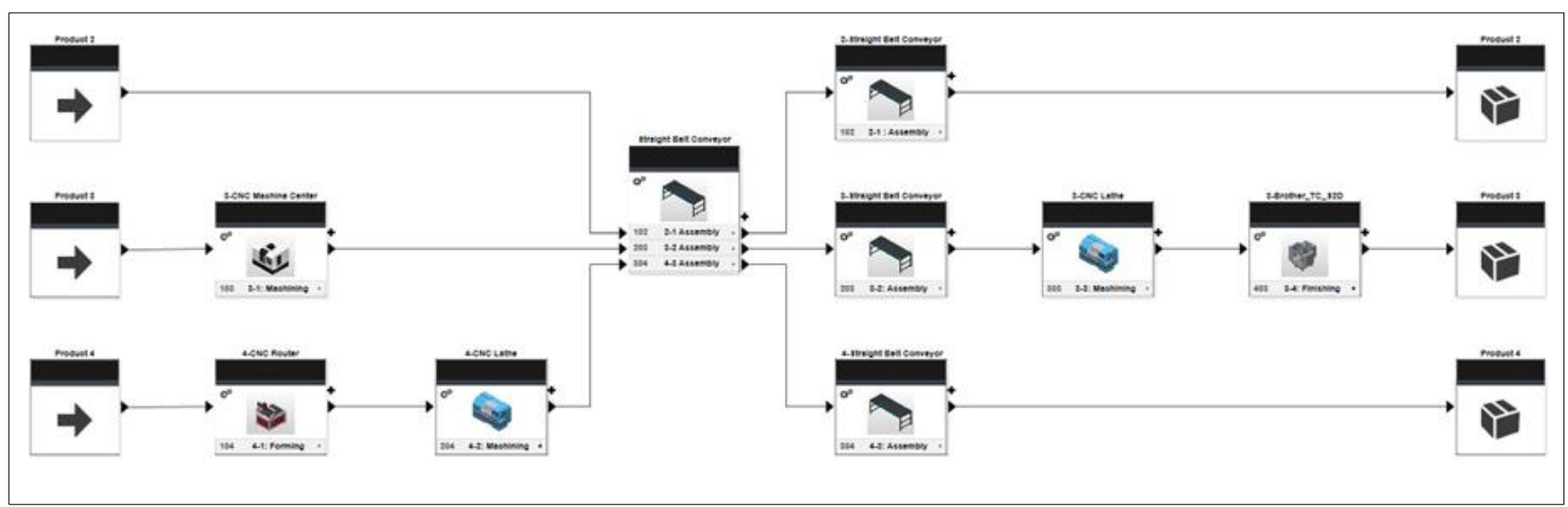

Fig. 10. Workflow for products 2-4

The workflow for products 2-4 can be seen schematically in Figure 10, while it is clearly defined by spatial dimensions in Fig.6. Product 2 consists only of the assembly part. The path of product 3 is storage, machine assembly, machining, finishing and finally storage. Product 4 starts in storage, followed by forming, machining, assembly and storage to finish.

The three products have the straight conveyor belt in common, this step was set with machining time 0 to represent the input on the belt. The conveyor belt travels about $32 \mathrm{~m}$, at a speed of $2 \mathrm{~m} /$ minute, it takes 16 minutes to travel the entire distance. But none of the products will make it completely, they will enter the separate belts and after 5 minutes (about $10 \mathrm{~m}$, one third of the total distance) in the belt, they will be removed and transported to the next step. During their journey in the belt they will have different assembly times. The batch sizes for the products are different: 2 is 50 units/load, 3 is 15 units/load and 4 is 1 unit/load. 
- 2-1 Assembly: 1 unit / $85 \mathrm{~s}$

- 3-1 Machining, 3-3 Machining, 3-4 Finishing: 1 pc/ $10 \mathrm{~s}$

- 3-2 Assembly: $1 \mathrm{pc} / 20 \mathrm{~s}$

- 4-1 Forming, 4-2 Machining, 4-3 Assembly: 1 pc / $1200 \mathrm{~s}$

Product 2 had 40 more pieces produced, product 3 had 1140 out of 1120, and product 4 had an additional $30 \%$ productivity. As mentioned earlier, a straight conveyor belt with machining time 0 was set up to mimic where the belt starts and the products converge. Both 3-CNC Lathe and 3-Brother_TC_S2D are affected by the speed of the conveyor belt per batch, about 5 minutes on the belt plus the additional 5 minutes for assembly compared to 2.5 minutes makes a difference, constantly waiting for the products reduces the working time of both machines to 25\% (Fig. 11). At the same time, the 3-CNC Machine Center is affected by this difference in processing time because it converts the product, but the product cannot go to the next station until the previous batch has been processed, blocking the machine for $49 \%$ of the time. Products 2 and 4 have very high production percentages, which shows that the design has been carefully thought out.

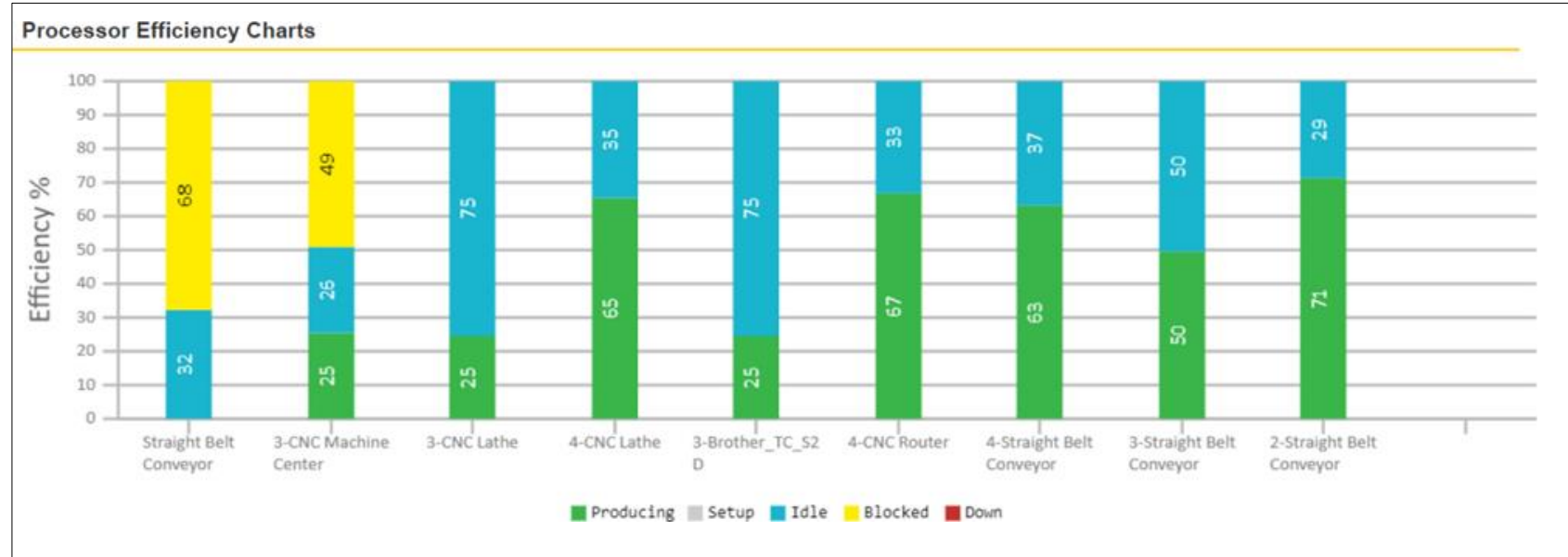

Fig. 11. Machine efficiency for products 234

The workflow for product 5 can be seen schematically in Fig. 12, while it is clearly defined with spatial dimensions in Fig.7.

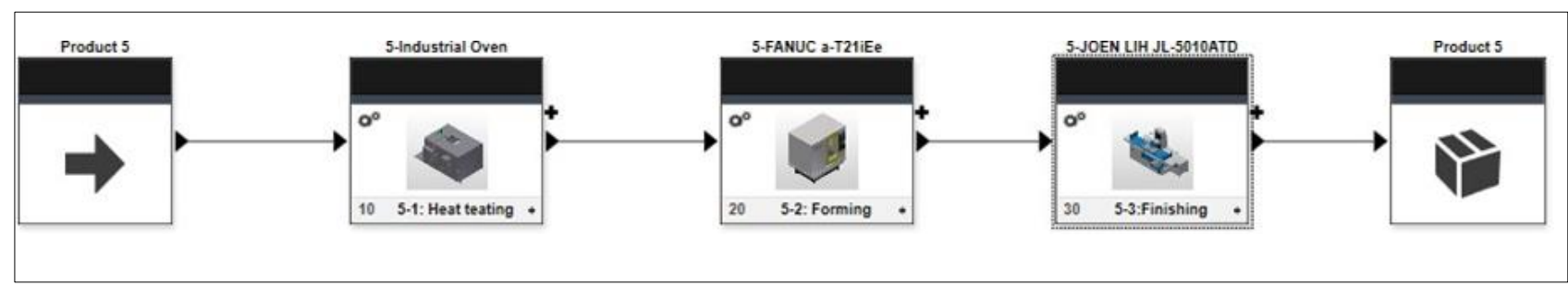

Fig. 12. Workflow for product 5

It starts with storage, followed by the sequence of heat treatment, forming, finishing and finally storage again. Each load carries 12 units and the processing time has been defined for all machines as follows:

- 5-1 heat treatment: 1 unit / $140 \mathrm{~s}$

- 5-2 Forming: 1 unit / $120 \mathrm{~s}$

- 5-3 Finishing: 1 unit/ $150 \mathrm{~s}$ 
Vujica Herzog, N.; Buchmeister, B. \& Ojstersek, R.: Use of Different Approaches f...

The simulations indicate that out of 150 pieces of the product 5156 pieces were produced, i.e. six extras. It can be clearly seen that the forming process always waits for the industrial furnace. This is because the processing time of the industrial oven is greater than that of the shaping process, so the FANUC machine has to wait until it is ready. When switching to the last step, the forming process has a shorter processing time, so the finishing department does not have to wait for the parts, but is always ready, increasing the production to 52\% (Fig. 14).

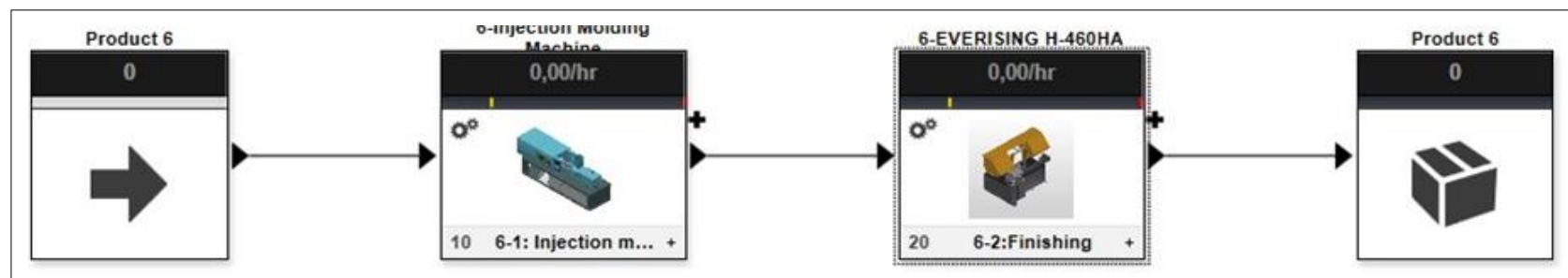

Fig. 13. Workflow for product 6

The workflow of product 6 can be seen schematically in Fig. 13, while it is clearly defined with spatial dimensions in Fig. 7. It starts with storage, followed by the sequence of injection moulding, finishing and finally storage again. Each load carries 50 units and the processing time was defined for all machines as follows:

- 6-1 Injection moulding: 1 unit / $5 \mathrm{~s}$

- 6-2 Finishing: 1 piece / $8 \mathrm{~s}$

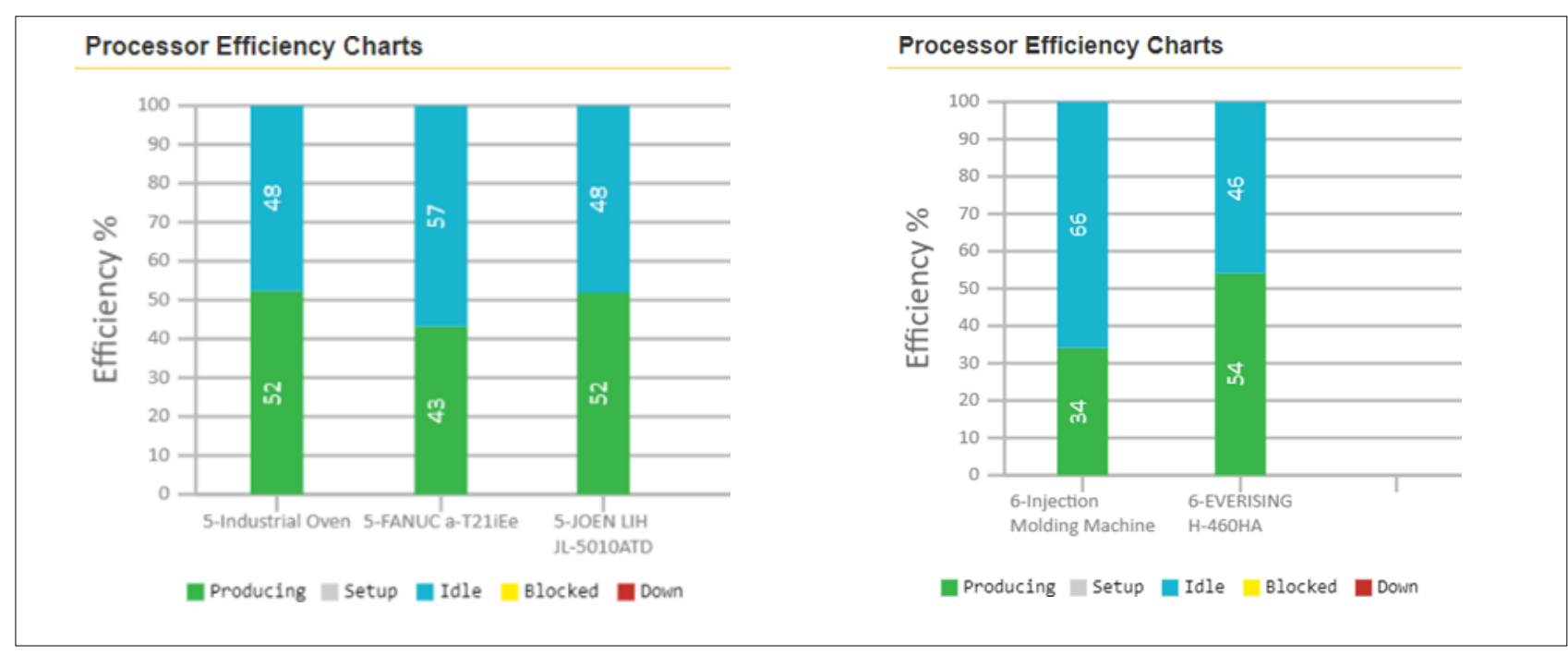

Fig. 14. Machine efficiency for product 5 (left) and product 6 (right)

Whenever injection moulding machines are used, a large number of pieces are needed because they require a very large initial investment. 3150 pieces were produced, an additional surplus of 50 pieces used to cover possible defects to avoid creating a sea of stock that hides production errors. A higher waiting time for injection moulding results from the stock output rate, which is actually fixed at 400 pieces/hour, and during the $113 \mathrm{~h}$ simulations it only "gives" 3211 pieces to the injection moulding section. 


\section{Conclusion}

Production design is a very complex task that can be solved using a variety of approaches, each of which offers its own solution to a particular problem. The range of knowledge in this field is wide, however, the goal of this paper is to understand how it works in general and to use the tools available to improve handmade sketches. The programs used are from the Autodesk family. For the 2D development of the layout, AutoCAD, AutoCAD Mechanical and AutoCAD Architecture were used. For 3D modelling, Autodesk Inventor Professional and for simulations Autodesk Process Analysis.

All the data needed for the problem presented was taken from the literature and supplemented with real life data. The first problem was to select the right location among several options in terms of transportation cost and number of moves per month. To solve this part, heuristic methods were used to make the best possible site selection. The layout design involved several steps to find the best option. Space allocation was done based on the processing area zone and elevated dimensions to have a better approximation to reality. Once the required space was defined, the cost was recalculated in terms of the number of movements between them and the workflow of each product, ranking them in order of importance. Microsoft Excel proved to be a useful tool to manage the amount of data presented.

The first decision related to the best factory distribution, either job shops or cellular manufacturing. Job shops were a better fit for our idea as cellular manufacturing was not possible due to the individual product flows. Block diagrams and CAD drawings showed us the best option. Using AutoCAD Mechanical and Architecture, as well as Autodesk Inventor Professional with the add-on package Autodesk Factory Design Utilities, we developed all 2D and 3D models for the factory layout, including workflows and specific machines.

For the final layout design, we ran simulations using the programme Autodesk Process Analysis to verify it. The data set consisted of distances derived from the layout design, machining time measures or output rate values along with time limited simulations. All product sequences were described and analysed. Of course, with other data, the results could be different.

The global idea made with this work can help us to better understand how a factory layout can be designed and elaborated. In the future, more specific information can be evaluated, such as which machines are overloaded or under loaded, where bottlenecks occur, inventory levels can be reduced, or efficiency can be increased.

\section{Acknowledgements}

The authors thank the reviewers and the editor for their comments. This work was supported by the Slovenian Research Agency under Grant P2-0190. 
Vujica Herzog, N.; Buchmeister, B. \& Ojstersek, R.: Use of Different Approaches f...

\section{References}

Autodesk Knowledge Network, Factory Design Utilities online help [web], Reachable: https://knowledge.autodesk.com/support/factory-design-utilities?sort=score [Date of access: 4/2021].

Buchmeister, B.; Palcic, I. \& Ojstersek, R. (2019). Artificial Intelligence in Manufacturing Companies and Broader: An Overview, Chapter 07 in DAAAM International Scientific Book 2019, pp. 081-098, B. Katalinic (Ed.), Published by DAAAM International, ISBN 978-3-902734-24-2, ISSN 1726-9687, Vienna, Austria, DOI: $10.2507 /$ daaam.scibook.2019.x

Francis, R.L. \& White, J.A. (1991). Facility Layout and Location - An Analytical Approach, 2nd edition, Prentice Hall, Engelwood Cliffs.

Gajšek, B. \& Vujica Herzog, N. (2020). Smart glasses in sustainable manual order picking systems. V: Grzybowska, K. (ur.), Awasthi, A. (ur.), Sawhney, R. (ur.). Sustainable logistics and production in industry 4.0 : new opportunities and challenges. [S. 1.]: Springer Nature, pp. 219-241.

Harari Y.; Bechar A.; Raschke U.; Riemer R. (2017). Automated Simulation-Based Workplace Design that Considers Ergonomics and Productivity. International Journal of Simulation Modelling, Vol. 16, No. 1, pp. 5-18.

Marjanović, U., Lalič, B., Medič, N., Presterr, J., Palčič, I. (2020). Servitization in manufacturing: role of antecedents and firm characteristics. International journal of industrial engineering and management. Vol. 11, No. 2, pp. 133-143.

Ojstersek, R., Buchmeister, B. \& Vujica Herzog, N. (2020). Use of data-driven simulation modeling and visual computing methods for workplace evaluation. Applied sciences. Vol. 10, No. 20, pp. 1-17.

Pinedo, M. L. (2009). Planning and scheduling in manufacturing services, New York: Slack, N. \& Brandon-Jones, Al. (2019). Operations Management, 9th edition. Prentice Hall.

Prester, J., Buchmeister, B. \& Palčič, I. (2018). Effects of advanced manufacturing technologies on manufacturing company performance. Strojniški vestnik., Vol. 64, No. 12, pp. 763-771.

Sule, D. R. (2005). Manufacturing facilities: location, planning, and design, 3rd edition, Boca Raton Florida: CRC Press, Taylor \& Francis Group, 2009.

Taha, H. (2006). Operations Research - An Introduction, 8th edition, Prentice Hall, /Upper Saddle River, NJ.

Tompkins, J.A., White, J.A., Bozer, Y.A., Tanchoco, J.M.A. (2002). Facilities Planning, 3rd edition, John Wiley, New York.

Vujica Herzog, N.; Buchmeister, B. \& Harih, G. (2019). Ergonomics workplace design for workers with disabilities, Chapter 12 in DAAAM International Scientific Book 2019, pp. 159-147, B. Katalinic (Ed.), Published by DAAAM International, ISBN 9783-902734-24-2, ISSN 1726-9687, Vienna, Austria, DOI: 10.2507/daaam.scibook.2019.x

Yang S. L., Xu Z. G., Wang J. Y. (2019). Modelling and Production Configuration Optimization for an Assembly Shop. Int. Journal of Simulation Modelling, Vol. 18, No. 2, p. 366-377. 